\title{
Temporal introduction patterns of invasive alien plant species to Australia
}

\author{
Brad R. Murray', Megan L. Phillips' \\ I School of the Environment, University of Technology Sydney, PO Box 123, Broadway, NSW 2007, Australia \\ Corresponding author: Brad R. Murray (Brad.Murray@uts.edu.au)
}

Academic editor: P. Pyšek | Received 23 November 2011 | Accepted 13 March 2012 | Published 16 May 2012

Citation: Murray BR, Phillips ML (2012) Temporal introduction patterns of invasive alien plant species to Australia. NeoBiota 13: 1-14. doi: 10.3897/neobiota.13.2422

\begin{abstract}
We examined temporal introduction patterns of 132 invasive alien plant species (IAPS) to Australia since European colonisation in 1770. Introductions of IAPS were high during 1810-1820 (10 species), 18401880 (51 species, 38 of these between 1840 and 1860) and 1930-1940 (9 species). Conspicuously few introductions occurred during 10-year periods directly preceding each introduction peak. Peaks during early European settlement (1810-1820) and human range expansion across the continent (1840-1860) both coincided with considerable growth in Australia's human population. We suggest that population growth during these times increased the likelihood of introduced plant species becoming invasive as a result of increased colonization and propagule pressure. Deliberate introductions of IAPS (104 species) far outnumbered accidental introductions (28 species) and were particularly prominent during early settlement. Cosmopolitan IAPS (25 species) and those native solely to South America (53 species), Africa (27 species) and Asia (19 species) have been introduced deliberately and accidentally to Australia across a broad period of time. A small number of IAPS, native solely to Europe (5 species) and North America (2 species), were all introduced to Australia prior to 1880 . These contrasting findings for native range suggest some role for habitat matching, with similar environmental conditions in Australia potentially driving the proliferation of IAPS native to southern-hemisphere regions. Shrub, tree and vine species dominated IAPS introduced prior to 1840 , with no grasses or forbs introduced during early colonisation. Since 1840 , all five growth forms have been introduced deliberately and accidentally in relatively large numbers across a broad period of time. In particular, a large number of grass and forb IAPS were deliberately introduced between 1840 and 1860, most likely a direct result of the introduction of legislation promoting intensive agriculture across large areas of the continent. Since the 1980s, only three IAPS have been introduced (all deliberately introduced forbs). The decline in IAPS introductions is most likely a reflection of both increased surveillance and biosecurity efforts and the likelihood that many potential IAPS are still within a pre-expansion lag period.
\end{abstract}

Copyright B. R. Murray, M. L. Phillips. This is an open access article distributed under the terms of the Creative Commons Attribution License 3.0 (CC-BY), which permits unrestricted use, distribution, and reproduction in any medium, provided the original author and source are credited. 


\section{Keywords}

Biological invasions, exotic plants, introduction history, invasion ecology, residence time

\section{Introduction}

Comparative analyses of alien plant introductions can pinpoint periods in history when different regions of the world have received particularly high numbers of species (e.g. Pyšek et al. 2003; Pyšek and Jarošík 2005). Such knowledge provides an important historic baseline for determining the factors driving the successful spread of introduced plant species (Phillips et al. 2010a). An understanding of temporal introduction patterns can inform management aimed at limiting the ecological, economic and social impacts of invasive alien plant species (IAPS) on native biodiversity.

Detailed knowledge of alien floras in Europe has led to deep insights into temporal patterns of plant introductions across much of the northern hemisphere (Kühn and Klotz 2003; Pyšek et al. 2005; Křivánek and Pyšek 2006; Chytrý et al. 2008, 2009; Lambdon et al. 2008; Hulme et al. 2009; Štajerová et al. 2009; Knapp et al. 2010; Kubešová et al. 2010; Vilà et al. 2010). At present, however, such detailed insights are less developed for some other regions of the world. In particular, despite a small but important body of work, we are only beginning to establish a comprehensive understanding of temporal patterns in the introduction of IAPS to Australia (e.g. Groves and Hosking 1998; Auld et al. 2003; Groves et al. 2005; Cook and Dias 2006; Caley et al. 2008). Given that recent estimates put the management of IAPS in Australia at more than $\$ 4$ billion AUD per year (Sinden et al. 2004), developing our understanding of all aspects of invasion success among alien species in Australia is an imperative.

Permanent settlement of Australia by European colonists began in earnest in 1770 . Since then, a total of 26,242 alien plant species have been introduced to Australia, with 2,739 of these species having become naturalized and over 130 now considered IAPS (Randall 2007). Plant species native to most major regions of the world including Asia, Africa, South America, North America and Europe have been introduced to Australia (Harris et al. 2007; Phillips et al. 2010b). In addition, alien species spanning a range of plant growth forms have been introduced both accidentally and deliberately (Groves et al. 2005). Answering the question of how traits of IAPS - such as method of introduction, native range and growth form - relate to interspecific variation in introduction times has the potential to yield important historical insight into the likelihood of successful invasion.

In this study, we compared temporal introduction patterns among IAPS introduced to Australia since European settlement. We related among-species variation in introduction times to the method of introduction of species, their native range and plant growth form. Our aim was to provide a detailed picture of when IAPS with different traits were introduced to Australia and to interpret our findings in the context of drivers of biological invasions and historical events during the development of Australia as a nation. 


\section{Methods}

We constructed a dataset of 132 IAPS in Australia using the latest compendium of the introduced flora of Australia (Randall 2007). This compendium defines invasive species (category ' $5 \mathrm{~A}$ ') as those that have been introduced to Australia from elsewhere and have spread rapidly, often forming monocultures and generally having serious high environmental and/or agricultural impacts. We excluded 13 of the ' $5 \mathrm{~A}$ ' species listed in Randall (2007) from our dataset and included three species not listed as '5A' (Acaciella angustissima, Asparagus aethiopicus, Senecio angulatus), with our justification for exclusions and inclusions detailed in Appendix 1.

We accessed the 'Australian Census of Cultivated Plants 2009' (Department of Agriculture, Fisheries and Forestry) to obtain the earliest year each of the study species has been recorded in Australia. The Census contains information gathered from public domain sources including over 600 plant nursery catalogues spanning 200 years, botanical and major garden plant species lists, Australian Quarantine and Inspection Service (AQIS) permitted import list, State department vegetation surveys and Commonwealth lists of imported species (R. Ingram, personal communication). We refer to the earliest year on record for each species as year of introduction. Given the high profile of the invasive species in our dataset, the extensive research, information and first-hand knowledge available in the literature for these species, we are confident that earliest records are tightly linked to actual introduction years.

We performed a literature search involving published papers, reports and government websites seeking information on the IAPS covering method of introduction to Australia, native geographic range and plant growth form. Method of introduction was recorded as either deliberate (e.g. ornamentals, forage or grafting plants, lawn species) or accidental (no known purposeful reason for introduction). The native range of each species was categorized as a single geographic region (Africa, Asia, Europe, North America, South America) or as cosmopolitan (i.e. the native range covered more than a single region). Each of the IAPS was placed into one of the following plant growth form categories: (1) Grass - monocotyledonous graminoids with narrow leaves growing from the base including Poaceae (Gramineae), Cyperaceae and Juncaceae; (2) Forb - self-supporting plants that have no woody stem above ground, with leaves and stems that may die down at the end of the growing season to the soil level; (3) Shrub - self-supporting plants that can produce a woody stem aboveground less than $6 \mathrm{~m}$ tall; (4) Tree - self-supporting plants with a woody stem more than $6 \mathrm{~m}$ tall; and (5) Vine - herbaceous or woody plants that climb or spread vertically or horizontally. Vines are usually considered as plants that must rely on external support to attain height. However, we classified other similar plants such as scramblers and rambling shrubs (which do not always require additional structural support) as one functional group (vines), consistent with Australia's first exotic vine inventory (Harris et al. 2007), as all of these species behave and alter the environments they invade in similar ways, such as climbing over and smothering vegetation. 


\section{Results}

Numbers of IAPS introduced to Australia have varied substantially over the years since European settlement (Fig. 1). Introduction numbers were comparatively high from 1810 to 1820 (10 species), 1840 to 1880 (51 species) and 1930 to 1940 (9 species). The 1840 to 1880 period was characterised by an especially high number of introductions between 1840 and 1860 (38 species). In contrast, low introduction numbers occurred during 10-year periods directly preceding each of the introduction peaks, with three IAPS introduced between 1800 and 1810, none introduced between 1830 and 1840 and one introduced between 1920 and 1930. Notably, only three IAPS have been introduced to Australia since 1980 .

Deliberate introductions of IAPS (104 species) began in 1770 and have continued to the present day (Fig. 1), far outnumbering accidental introductions (28 species). Indeed, deliberate introductions were particularly prominent during early settlement with no IAPS introduced accidentally either prior to 1840, or in fact since 1970 . Generally, species native to all geographic regions have been introduced deliberately (Fig. 2a) and accidentally (Fig. 2b) to Australia across a broad period of time, with no particular region dominating any of the introduction peaks. The native ranges of the majority of IAPS extend over a single geographic region, with most species native to South America (53 species), Africa (27 species) and Asia (19 species). Interestingly, only five species were found to be native solely to Europe and only two species native solely to North America, and all seven were introduced prior to 1880. A total of 25 IAPS were found to be cosmopolitan (Table 1), all introduced across a broad period of time (Fig. 2).

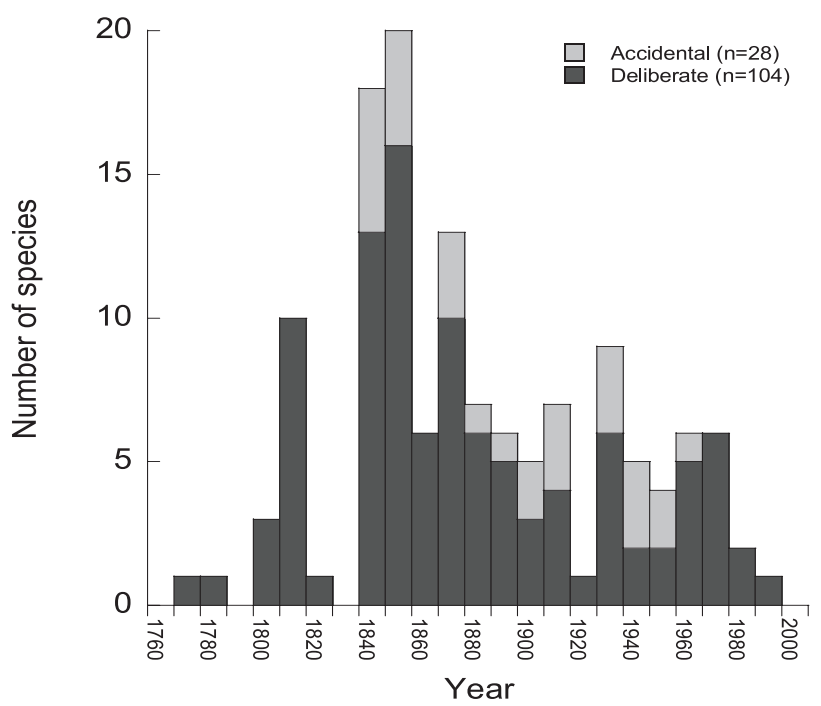

Figure I. Frequency distribution of introduction times of invasive alien plant species in Australia in relation to method of introduction (accidental or deliberate). 
(a)

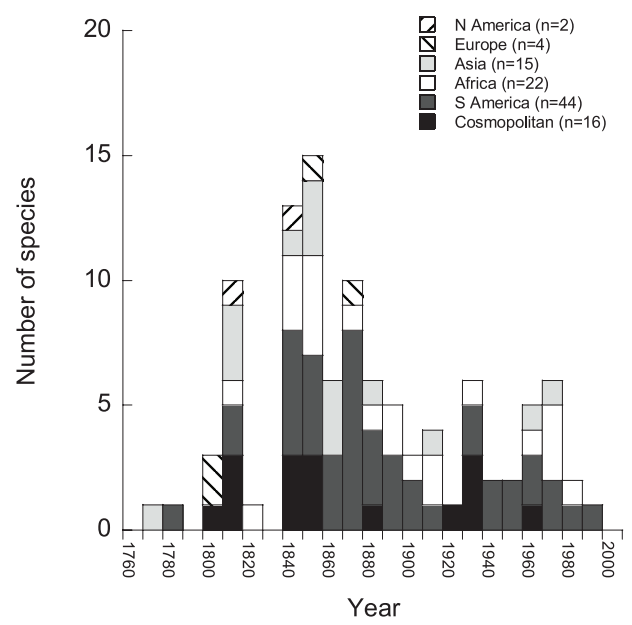

(b)

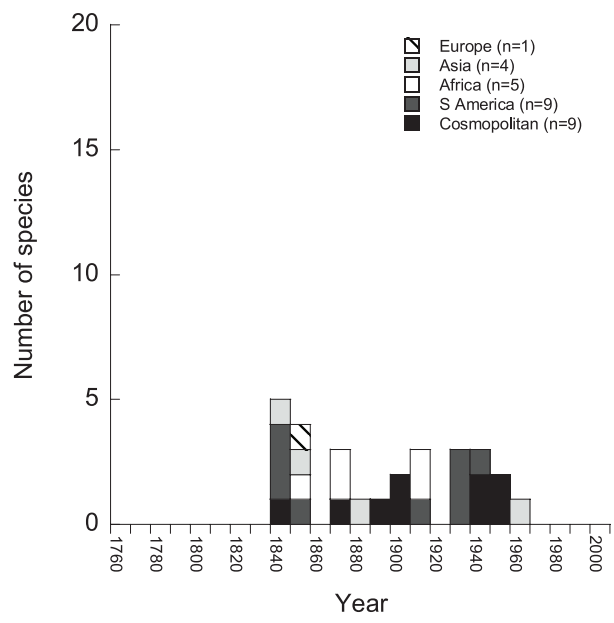

Figure 2. Frequency distributions of $\mathbf{a}$ deliberate and $\mathbf{b}$ accidental introduction times of invasive alien plant species in Australia in relation to native geographic range. Rubus fruticosus is not included in (a) as it is an aggregate species consisting of 14 closely-related species (some of which may be hybrids) from a range of different regions.

Shrub, tree and vine species dominated IAPS introduced (all deliberately) prior to 1840 , with no grasses or forbs introduced during early colonisation (Fig. 3). Since 1840, all five growth forms have been introduced deliberately (Fig. 3a) and accidentally (Fig. 3b) in relatively large numbers across a broad period of time. One par-

Table I. Cosmopolitan species, their method of introduction and native geographic ranges.

\begin{tabular}{l|l|l}
\hline Species & Introduction & Native range \\
\hline Acaciella angustissima & Deliberate & North America, South America \\
\hline Andropogon virginicus & Accidental & North America, South America \\
\hline Annona glabra & Deliberate & Africa, North America, South America \\
\hline Arundo donax & Deliberate & Asia, Europe \\
\hline Baccharis halimifolia & Deliberate & North America, South America \\
\hline Cardiospermum grandiflorum & Deliberate & Africa, North America, South America \\
\hline Cenchrus ciliaris & Accidental & Africa, Asia \\
\hline Gloriosa superba & Deliberate & Africa, Asia \\
\hline Hydrocotyle bonariensis & Accidental & Africa, North America, South America \\
\hline Ilex aquifolium & Deliberate & Africa, Asia, Europe \\
\hline Ipomoea cairica & Deliberate & Africa, Asia \\
\hline Juncus articulatus & Accidental & Africa, Asia, Europe, North America \\
\hline Macroptilium atropurpureum & Accidental & North America, South America \\
\hline Neonotonia wightii & Deliberate & Africa, Asia \\
\hline Olea europaea & Deliberate & Africa, Asia, Europe \\
\hline Opuntia imbricata & Deliberate & North America, South America \\
\hline
\end{tabular}




\begin{tabular}{l|l|l}
\hline Parietaria judaica & Accidental & Africa, Asia, Europe \\
\hline Parkinsonia aculeata & Deliberate & North America, South America \\
\hline Parthenium hysterophorus & Accidental & North America, South America \\
\hline Phyla canescens & Deliberate & North America, South America \\
\hline Prunus cerasus & Accidental & Asia, Europe \\
\hline Ricinus communis & Deliberate & Africa, Asia, Europe \\
\hline Salvia coccinea & Deliberate & North America, South America \\
\hline Tamarix aphylla & Deliberate & Africa, Asia \\
\hline Verbesina encelioides & Accidental & North America, South America \\
\hline
\end{tabular}

(a)

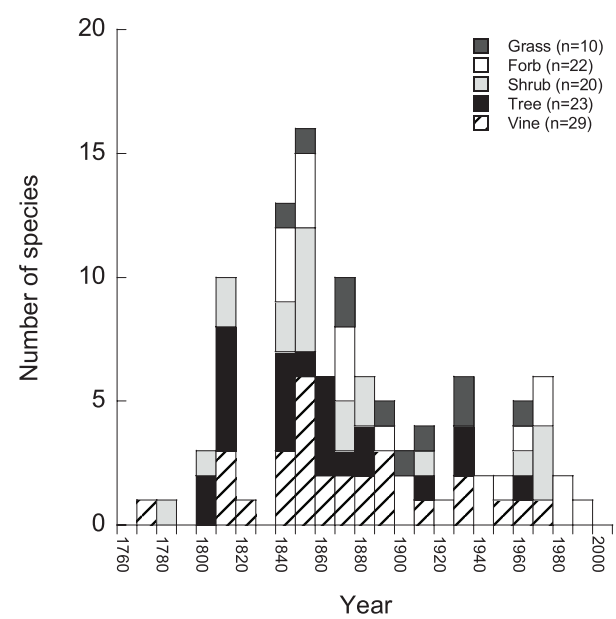

(b)

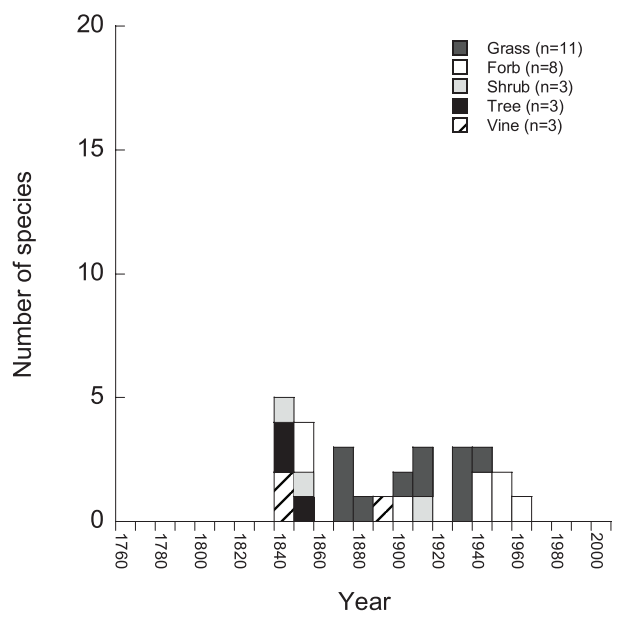

Figure 3. Frequency distributions of $\mathbf{a}$ deliberate and $\mathbf{b}$ accidental introduction times of invasive alien plant species in Australia in relation to plant growth form.

ticular growth-form pattern that emerged showed that a comparatively large number of grasses and forbs were deliberately introduced between 1840 and 1880 and since then (up until 1970) accidental introductions of grasses and forbs have been especially prominent. The small number of IAPS introduced since 1980 have all been forbs.

\section{Discussion}

We identified three distinct periods in Australia's recent history when introductions of IAPS were particularly high. We describe a simple null model that relates increased introductions of IAPS to increases in both 'colonization pressure' and 'propagule pressure' (sensu Lockwood et al. 2009). For colonization pressure, increased numbers of IAPS introductions under our model are linked to increases in the total number of all alien plant species introduced during peak IAPS periods. Here, the introduction of large numbers of alien plant species raises the likelihood 
that more invasive species will emerge. Empirical evidence for this idea is scarce, however, recent work in Europe provides some support for our null model. Chytrý et al. (2012) have shown that areas predicted to have an increase in alien species in projected models for future land-use change will also most likely harbour more serious invaders. For propagule pressure, increased IAPS introductions under our model are linked to increases in the number of individuals of each species in each 'release' event and the number of discrete release events. Previous studies provide some support for our null model, with findings in other systems that propagule pressure is a key driver of both establishment success (Lockwood et al. 2005) and invasive spread (Colautti et al. 2006; Johnston et al. 2009) in a range of taxa and across a variety of geographic regions.

For Australia, as is common in many retrospective studies of invasion (Pyšek et al. 2010), data on colonization pressure and propagule pressure for IAPS are hard to come by (but see, for instance, Cassey et al. 2004). To test our null model and in the absence of such data, future studies might explore proxies of these pressures. For example, the total number of recorded alien plant species introduced to Australia from different regions of the world could act as a proxy for colonization pressure (e.g. Phillips et al. 2010a), while occurrence in nursery catalogues could act as a proxy for propagule pressure (e.g. Pemberton and Liu 2009). Previous studies have used measures of human population size as indicators of these pressures and related them to the presence of alien species (Lonsdale 1999; McKinney 2002; Pyšek et al. 2002; Essl et al. 2011). Effectively, increased colonization and propagule pressure of alien plant species is predicted to be a function of human population size. Simply, more people transport more species (colonization pressure) and more individuals of the same species (propagule pressure) by either bringing them into a country or by spreading them around a country.

Support for a link between human population size and the introduction of IAPS in Australia might be obtained if substantial increases in Australia's population coincided with increased introductions of IAPS. We accessed data from the Australian Bureau of Statistics, specifically the database 'Australian Historical Population Statistics 2008' showing changes in Australia's population over time (http://www.abs.gov.au, accessed February 2012). We compared increases in both IAPS and Australia's population during both peaks, and importantly, during periods of low introductions of IAPS directly prior to the peaks. We found that peaks during early European colonization (1810$1820)$ and human range expansion across the continent (1840-1860) both coincided with considerable growth in Australia's human population (Fig. 4). The introduction lows in the preceding periods were associated with comparatively smaller increases in Australia's population. These correlated events provide support for the idea that human population increase could be a substantial driver of increased introductions of IAPS via increased colonization and propagule pressure.

Interestingly, unlike the first two peaks in IAPS, the third peak (1930-1940) did not coincide with a marked increase in Australia's population (Fig. 4). During the preceding period (1920-1930), there was a much larger increase in Australia's 
(a) Early European colonization

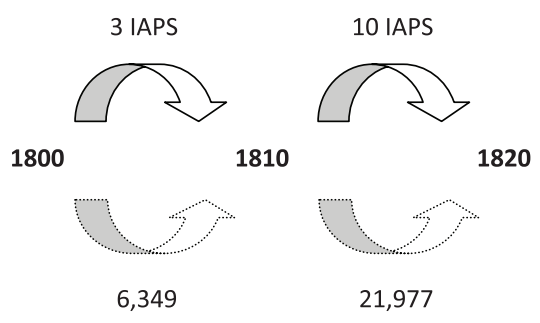

(b) Human range expansion

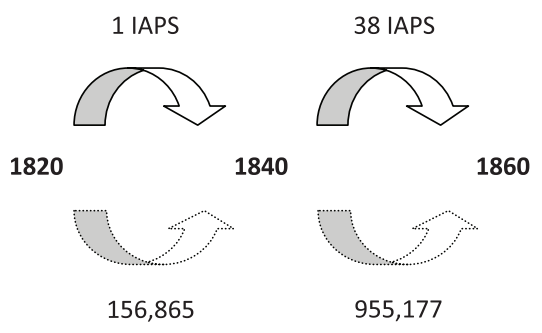

(c) Pre-World War II

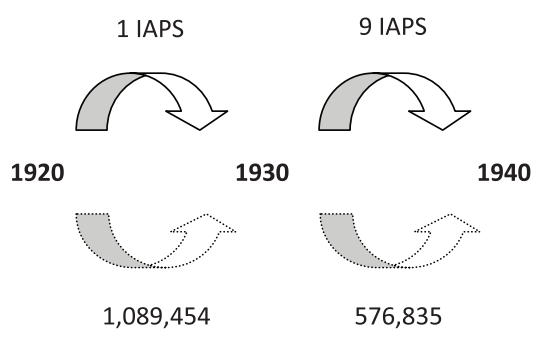

Figure 4. Increases in IAPS (numbers of species above arrows) and Australia's human population (number of people below arrows) in relation to time (years shown between arrows) during a early European colonization $\mathbf{b}$ human range expansion and $\mathbf{c}$ pre-World War II.

population (c. 1 million people) but only one IAPS was introduced. Nevertheless, Australia’s population still increased by half-a-million people between 1930 and 1940 , which could still explain to some extent the peak in IAPS. The significant low in IAPS introductions between 1920 and 1930 might be a result of economic difficulties during the Great Depression during the 1920s. At such a time, costs associated with importing species might have been avoided. It is also likely that during such financially challenging times that hobbies such as gardening would not have been a high priority, potentially reducing the influx of ornamental plants. Perhaps the subsequent peak in introductions may be accounted for by more targeted introductions of species during pre-World War II immigration to Australia during the 1930s. A goal of future work will be to unravel the pathways of introduction of IAPS, particularly during the 1930-1940 
peak, to determine why IAPS introductions peaked during a time when Australia's population showed a comparatively smaller increase.

What explains the predominance of IAPS in Australia that are native to the southern hemisphere? This finding suggests that invaders from other continents might possess a degree of climatic pre-adaptation or habitat matching that facilitates invasiveness (e.g. see Thuiller et al. 2005; Pyšek et al. 2009). Similar biotic and abiotic conditions in southern-hemisphere regions might underpin the proliferation of IAPS from these regions in Australia. Recent work on 26 plant species introduced to Australia has shown that alien species are able to occupy climate niches in their new range that differ substantially from those of their native range (Gallagher et al. 2010). This suggests that climatic pre-adaptation might not be so important for IAPS in Australia, and in fact points to other potential explanations. For instance, introduction-history features (e.g. colonization and propagule pressures) may be stronger in species from these regions because of their geographic proximity (Pyšek et al. 2004). Nevertheless, it is important to note that more than half of the 26 species examined in Gallagher et al. (2010) are not currently considered nationally invasive (category ' $5 \mathrm{~A}$ ' in Randall 2007); thus, a habitat-matching mechanism is still potentially important for IAPS in Australia.

Our work has shown that most IAPS were deliberately introduced to Australia. This is not surprising, with previous studies documenting the importance of deliberate introductions in the increase in alien plant species in Australia (Kloot 1987; Carr 1993; Groves et al. 2005). We also know that the proportion of deliberate to accidental introductions does not differ significantly between the pool of IAPS and the pool of naturalized non-invasive alien plant species in Australia (Phillips et al. 2010b). Although deliberate introductions dominate the pool of IAPS, this does not mean that alien plant species are any more likely to become invasive via this method of introduction. Interestingly, we found that deliberate introductions were particularly prominent during early settlement with no IAPS introduced accidentally prior to 1840. Species were introduced deliberately by early British colonists most likely as garden ornamentals (Cytisus scoparius, Ipomoea indica), food for people and fodder for animals (Ulex europaeus and Opuntia monacantha, the latter also probably used to make whiskey) and for use in health and medicine (e.g. castor oil from Ricinus communis).

No grass or forb IAPS were introduced during early colonisation but a comparatively large number of these were deliberately introduced between 1840 and 1860. The later introduction of forb and grass IAPS is associated with a period of time in Australia's history when land 'selection' became prominent. Selection allowed settlers to have free choice of government land in some Australian colonies under land legislation acts introduced in the 1860s (Roberts 1924). These acts provided opportunities for intensive agricultural productivity by settlers with limited financial means. As such, much land was opened up to farming and in the process many grasses currently recognized as IAPS were introduced both deliberately and accidentally. In fact, since 1860 and up until 1970, accidental introductions of grasses and forbs have been especially prominent. These growth forms are especially prone to accidental introduction due to their prolific production of many minute seeds, often which have specific adhesive adaptations like awns, hairs and spines 
that can stick to animal coats and clothing (Groves et al. 2005). Some species, including Cenchrus ciliaris which arrived in Australia in 1875, were initially recorded as accidental introductions to Australia, but were later purposefully spread throughout the country for various reasons such as for use as fodder crops and land stabilisation (Humphreys 1967).

Since the 1980s, only three IAPS have been introduced (all deliberately introduced forbs). The decline in IAPS introductions is most likely due to two factors. First, increased surveillance and biosecurity efforts have been successful in controlling the influx of alien species likely to become IAPS. For example, accidental introductions are much less likely due to seed cleaning techniques and quarantine services ensuring minimal contamination (Mack and Lonsdale 2001). Second, some potential IAPS might still be within a pre-expansion lag period (they are still 'sleeping', Groves 2006). For instance, there may not yet have been enough time to register the spread and impacts of alien species with long juvenile periods as IAPS (e.g. Auld et al. 2003). However, Daehler (2009) has recently reported much shorter lag times for long-lived species than previously estimated from indirect observations. Although the study was based on tropical species, it does provide tantalizing evidence that lag times may not be as long as generally thought, and that current biosecurity efforts halting the introduction of potentially serious invasive plant species are effective.

\section{Acknowledgements}

We thank the members of the Biodiversity Research Group at UTS, Carl Arbegast, Petr Pyšek and an anonymous reviewer for providing helpful comments on a draft of the paper. We are grateful to Robert Ingram of the Department of Agriculture, Fisheries and Forestry for kindly providing access to the Census of Cultivated Plants 2009. This paper is dedicated to the memory of Ivy Murray.

\section{References}

Auld B, Morita H, Nishida T, Ito M, Michael P (2003) Shared exotica: Plant invasions of Japan and south eastern Australia. Cunninghamia 8: 147-152.

Caley P, Groves RH, Barker R (2008) Estimating the invasion success of introduced plants. Diversity and Distributions 14: 196-203. doi: 10.1111/j.1472-4642.2007.00440.x

Carr GW (1993) Exotic flora of Victoria and its impact on indigenous biota. In: Foreman DB, Walsh NG (Eds) Flora of Victoria, Vol. 1, Introduction, Inkata Press, Melbourne, 256-297.

Cassey P, Blackburn TM, Sol D, Duncan RP, Lockwood JL (2004) Global patterns of introduction effort and establishment success in birds. Proceedings of the Royal Society of London B 272: S405-S408. doi: 10.1098/rsbl.2004.0199 
Chytrý M, Maskell LC, Pino J, Pyšek P, Vilà M, Font X, Smart SM (2008) Habitat invasions by alien plants: a quantitative comparison among Mediterranean, subcontinental and oceanic regions of Europe. Journal of Applied Ecology 45: 448-458. doi: 10.1111/j.1365-2664.2007.01398.x

Chytrý M, Pyšek P, Wild J, Maskell LC, Pino J, Vilà M (2009) European map of alien plant invasions, based on the quantitative assessment across habitats. Diversity and Distributions 15: 98-107. doi: 10.1111/j.1472-4642.2008.00515.x

Chytrý M, Wild J, Pyšek P, Jarošík V, Dendoncker N, Reginster I, Pino J, Maskell LC Vilà M, Pergl J, Kühn I, Spangenberg JH, Settele J (2012) Projecting trends in plant invasions in Europe under different scenarios of future land-use change. Global Ecology and Biogeography 21: 75-87. doi: 10.1111/j.1466-8238.2010.00573.x

Colautti RI, Grigorovich IA, MacIsaac HJ (2006) Propagule pressure: a null model for biological invasions. Biological Invasions 8: 1023-1037. doi: 10.1007/s10530-005-3735-y

Cook GD, Dias L (2006) It was no accident: deliberate plant introductions by Australian government agencies during the 20th century. Australian Journal of Botany 54: 601-625. doi: 10.1071/BT05157

Daehler CC (2009) Short lag times for invasive tropical plants: evidence from experimental plantings in Hawai'i. PLoS ONE 4: e4462. doi: 10.1371/journal.pone.0004462

Essl F, Dullinger S, Rabitsch W, Hulme PE, Hülber K, Jarošík V, Kleinbauer I, Krausmann F, Kühn I, Nentwig W, Vilà M, Genovesi P, Gherardil F, Desprez-Loustau M-L, Roques A, Pyšek P (2011) Socioeconomic legacy yields an invasion debt. Proceedings of the National Academy of Sciences USA 108: 203-207. doi: 10.1073/pnas.1011728108

Gallagher RV, Beaumont LJ, Hughes L, Leishman MR (2010) Evidence for climatic niche and biome shifts between native and novel ranges in plant species introduced to Australia. Journal of Ecology 98: 790-799. doi: 10.1111/j.1365-2745.2010.01677.x

Groves RH (2006) Are some weeds sleeping? Some concepts and reasons. Euphytica 148: 111120. doi: 10.1007/s10681-006-5945-5

Groves RH, Hosking JR (1998) Recent Incursions of Weeds to Australia 1971-1995. Cooperative Research Centre for Weed Management Systems, Technical Series No. 3, Adelaide.

Groves RH, Boden R, Lonsdale M (2005) Jumping the Garden Fence: Invasive Garden Plants in Australia and Their Environmental and Agricultural Impacts. WWF-Australia, Ultimo.

Harris CJ, Murray BR, Hose GC, Hamilton MA (2007) Introduction history and invasion success in exotic vines introduced to Australia. Diversity and Distributions 13: 467-75. doi: 10.1111/j.1472-4642.2007.00375.x

Hulme P, Pyšek P, Nentwig W, Vilà M (2009) Will threat of biological invasions unite the European Union? Science 324: 40-41. doi: 10.1126/science.1171111

Humphreys LR (1967) Buffel Grass (Cenchrus ciliaris) in Australia. Tropical Grasslands 1: 123-134.

Johnston EL, Piola RF, Clark GF (2009) The role of propagule pressure in invasion success. In: Rilov G, Crooks JA (Eds) Biological Invasions in Marine Ecosystems, Springer-Verlag, Berlin, 133-151. doi: 10.1007/978-3-540-79236-9_7 
Kloot PM (1987) The naturalised flora of South Australia. 3. Its origin, introduction, distribution, growth forms and significance. Journal of the Adelaide Botanic Gardens 10: 99-111.

Knapp S, Kühn I, Stolle J, Klotz S (2010) Changes in the functional composition of a Central European urban flora over three centuries. Perspectives in Plant Ecology, Evolution and Systematics 12: 235-244. doi: 10.1016/j.ppees.2009.11.001

Křivánek M, Pyšek P (2006) Predicting invasions by woody species in a temperate zone: a test of three risk assessment schemes in the Czech Republic (Central Europe). Diversity and Distributions 12: 319-327. doi: 10.1111/j.1366-9516.2006.00249.x

Kubešová M, Moravcová L, Suda J, Jarošík V, Pyšek P (2010) Naturalized plants have smaller genomes than their non-invading relatives: a flow cytometric analysis of the Czech alien flora. Preslia 82: 81-96.

Kühn I, Klotz S (2003) The alien flora of Germany: basics from a new German database. In: Child LE, Brock JH, Brundu G, Prach K, Pyšek P, Wade PM, Williamson M (Eds) Plant Invasions: Ecological Threats and Management Solutions, Backhuys, Leiden, 89-100.

Lambdon PW, Pyšek P, Basnou C, Hejda M, Arianoutsou M, Essl F, Jarošík V, Pergl J, Winter M, Anastasiu P, Andriopoulos P, Bazos I, Brundu G, Celesti-Grapow L, Chassot P, Delipetrou P, Josefsson M, Kark S, Klotz S, Kokkoris Y, Kühn I, Marchante H, Perglová I, Pino J, Vilà M, Zikos A, Roy DB, Hulme PE (2008) Alien flora of Europe: species diversity, temporal trends, geographical patterns and research needs. Preslia 80: 101-149.

Lockwood JL, Cassey P, Blackburn T (2005) The role of propagule pressure in explaining species invasions. Trends in Ecology \& Evolution 20: 223-228. doi: 10.1016/j.tree.2005.02.004

Lockwood JL, Cassey P, Blackburn TM (2009) The more you introduce the more you get: the role of colonization pressure and propagule pressure in invasion ecology. Diversity and Distributions 15: 904-910. doi: 10.1111/j.1472-4642.2009.00594.x

Lonsdale WM (1999) Global patterns of plant invasions and the concept of invisibility. Ecology 80: 1522-1536. doi: 10.1890/0012-9658(1999)080[1522:GPOPIA]2.0.CO;2

Mack RN, Lonsdale WM (2001) Humans as global plant dispersers: getting more than we bargained for. Bioscience 51: 95-102. doi: 10.1641/0006-3568(2001)051[0095:HAGP DG]2.0.CO;2

McKinney ML (2002) Influence of settlement time, human population, park shape and age, visitation and roads on the number of alien plant species in protected areas in the USA. Diversity and Distributions 8: 311-318. doi: 10.1046/j.1472-4642.2002.00153.x

Pemberton RW, Liu H (2009) Marketing time predicts naturalization of horticultural plants. Ecology 90: 69-80. doi: 10.1890/07-1516.1

Phillips ML, Murray BR, Pyšek P, Pergl J, Jarošík V, Chytrý M, Kühn I (2010a) Plants species of the Central European flora as aliens in Australia. Preslia 82: 465-482.

Phillips ML, Murray BR, Leishman MR, Ingram R (2010b) The naturalisation to invasion transition: Are there introduction-history correlates of invasiveness in exotic plants of Australia? Austral Ecology 35: 695-703. doi: 10.1111/j.1442-9993.2009.02076.x

Pyšek P, Jarošík V (2005) Residence time determines the distribution of alien plants. In: Inderjit (Ed) Invasive plants: ecological and agricultural aspects, Birkhäuser Verlag-AG, Basel, 77-96. 
Pyšek P, Jarošík V, Chytrý M, Kropáč Z, Tichý L, Wild J (2005) Alien plants in temperate weed communities: prehistoric and recent invaders occupy different habitats. Ecology 86: 772-785. doi: 10.1890/04-0012

Pyšek P, Jarošík V, Hulme PE, Kühn I, Wild J, Arianoutsou M, Bacher S, Chiron F, Didžiulis V, Essl F, Genovesi P, Gherardi F, Hejda M, Kark S, Lambdon PW, Desprez-Loustau A-M, Nentwig W, Pergl J, Poboljšaj K, Rabitsch W, Roques A, Roy DB, Solarz W, Vila M, Winter M (2010) Disentangling the role of environmental and human pressures on biological invasions across Europe. Proceedings of the National Academy of Sciences USA 107: 12157-12162. doi: 10.1073/pnas.1002314107

Pyšek P, Jarošík V, Kučera T (2002) Patterns of invasion in temperate nature reserves. Biological Conservation 104: 13-24. doi: 10.1016/S0006-3207(01)00150-1

Pyšek P, Jarošík V, Pergl J, Randall R, Chytrý M, Kühn I, Lubomír Tichý, Danihelka J, Chrtek J jun, Sádlo J (2009) The global invasion success of Central European plants is related to distribution characteristics in their native range and species traits. Diversity and Distributions 15: 891-903. doi: 10.1111/j.1472-4642.2009.00602.x

Pyšek P, Richardson DM, Williamson M (2004) Predicting and explaining plant invasions through analysis of source area floras: some critical considerations. Diversity and Distributions 10: 179-187. doi: 10.1111/j.1366-9516.2004.00079.x

Pyšek P, Sádlo J, Mandák B, Jarošík V (2003) Czech alien flora and a historical pattern of its formation: what came first to Central Europe? Oecologia 135: 122-130.

Randall RP (2007) The introduced flora of Australia and its weed status. CRC for Australian Weed Management, Department of Agriculture and Food, Western Australia, University of South Australia, Adelaide.

Roberts SH (1924) History of Australian Land Settlement, 1788-1920. Melbourne University Press, Melbourne.

Sinden J, Jones R, Hester S, Odom D, Kalisch C, James R, Cacho O (2004) The economic impact of weeds in Australia, Technical Series no. 8, CRC for Australian Weed Management, Australia.

Štajerová K, Šmilauerová M, Šmilauer P (2009) Arbuscular mycorrhizal symbiosis of herbaceous invasive neophytes in the Czech Republic. Preslia 81: 341-355.

Thuiller W, Richardson DM, Pyšek P, Midgley GF, Hughes GO, Rouget M (2005) Nichebased modelling as a tool for predicting the risk of alien plant invasions at a global scale. Global Change Biology 11: 2234-2250. doi: 10.1111/j.1365-2486.2005.001018.x

Vilà M, Basnou C, Pyšek P, Josefsson M, Genovesi P, Gollasch S, Nentwig W, Olenin S, Roques A, Roy D, Hulme PE, DAISIE partners (2010) How well do we understand the impacts of alien species on ecological services? A pan-European cross-taxa assessment. Frontiers in Ecology and the Environment 8: 135-144. doi: 10.1890/080083 


\section{Appendix I}

Invasive ('5A') taxa in Randall (2007) that were excluded from our study and the reason for their exclusion.

\begin{tabular}{l|l}
\hline Taxa & Reason for exclusion \\
\hline Acacia boliviana & $\begin{array}{l}\text { Non-current synonym for Acaciella angustissima which is not listed at all } \\
\text { in Randall (2007); Acaciella angustissima is included in our dataset given } \\
\text { the 5A status of Acacia boliviana }\end{array}$ \\
\hline Crocosmia X crocosmiiflora & $\begin{array}{l}\text { An engineered horticultural hybrid, thus quite distinct and not } \\
\text { comparable to all other invasive species in our dataset }\end{array}$ \\
\hline Myrsiphyllum asparagoides & $\begin{array}{l}\text { Non-current synonym for Asparagus asparagoides } \text { which is listed as 5A in } \\
\text { Randall (2007) and already in our dataset }\end{array}$ \\
\hline Panicum maxiumum & $\begin{array}{l}\text { Not listed as naturalized (N) in Randall (2007) and no literature } \\
\text { evidence for naturalized status; our dataset contains species that are both } \\
\text { naturalized and invasive }\end{array}$ \\
\hline Pinus elliotii & A gymnosperm, our dataset contains angiosperms only \\
\hline Protasparagus aethiopicus & A gymnosperm, our dataset contains angiosperms only \\
\hline Protasparagus plumosus & $\begin{array}{l}\text { Non-current synonym for } \text { Asparagus aethiopicus which is not listed as 5A } \\
\text { in Randall (2007); Asparagus aethiopicus is included in our dataset given } \\
\text { the 5A status of Protasparagus aethiopicus }\end{array}$ \\
\hline Salvinia molesta & $\begin{array}{l}\text { Non-current synonym for } \text { Asparagus plumosus } \text { which is listed as 5A in } \\
\text { Randall (2007) and already in our dataset }\end{array}$ \\
\hline Senecio tamoides & A fern, our dataset contains angiosperms only \\
\hline Tradescantia albiflora & $\begin{array}{l}\text { A taxonomic misapplication of Senecio angulatus which is not listed as 5A } \\
\text { in Randall (2007); Senecio angulatus is included in our dataset given the } \\
\text { 5A status of Senecio tamoides }\end{array}$ \\
\hline Turnera subulata & $\begin{array}{l}\text { Not listed as naturalized (N) in Randall (2007) and no literature } \\
\text { evidence for naturalized status; our dataset contains species that are both } \\
\text { naturalized and invasive }\end{array}$ \\
\hline $\begin{array}{l}\text { Non-current synonym for Tradescantia fluminensis which is listed as 5A in } \\
\text { Randall (2007) and already in our dataset }\end{array}$ \\
\hline $\begin{array}{l}\text { Not listed as naturalized (N) in Randall (2007) and no literature } \\
\text { evidence for naturalized status; our dataset contains species that are both } \\
\text { naturalized and invasive }\end{array}$ \\
\hline
\end{tabular}

